\title{
Blood sucking Diptera (Culicidae, Psychodidae, Simuliidae) in forest fragment under impact of dam in the borderland of Rio Grande do Sul and Santa Catarina states, Brazil
}

\author{
Dípteros hematófagos (Culicidae, Psychodidae, Simuliidae) \\ em fragmento de floresta sob impacto de barragem na fronteira \\ dos estados do Rio Grande do Sul e Santa Catarina, Brasil
}

\author{
Gerson Azulim Muller $^{I^{*}}$ Maira Aparecida Dalavequia ${ }^{\mathrm{I}}$ \\ Glauber Wagner ${ }^{\mathrm{I}}$ Carlos Brisola Marcondes ${ }^{\mathrm{II}}$
}

\section{- NOTE -}

\begin{abstract}
The study of Diptera of medical importance in areas affected by dam constructions is very important due to the possibility of the occurrence of diseases transmitted by these species. Collections were performed during 2010 and 2011 in an area under impact of a dam on the Uruguai River in the borderland of Rio Grande do Sul and Santa Catarina states. Insects were collected using suction tubes and Shannon trap, also immature live forms were obtained by manual collect. Eight-hundred sixty-one Diptera insects were captured, including Haemagogus leucocelaenus (Culicidae), Aedes albopictus (Culicidae), three species of Anopheles spp. (Culicidae), two of Plebotominae and three distinct Simuliidae species. The Diptera fauna in the area is diversified and species with medical importance were identified before and after reservoir filling.
\end{abstract}

Key words: dams, Diptera, environmental impact, vectors.

\section{RESUMO}

O estudo de dípteros de importância médica em áreas afetadas pelas construções de barragens é muito importante, devido à possibilidade de ocorrência de doenças transmitidas por essas espécies. As coletas foram realizadas entre 2010 e 2011 em uma área sob o impacto de uma barragem no Rio Uruguai, na fronteira entre os estados do Rio Grande do Sul e Santa Catarina. Os insetos foram coletados através de tubos de sucção e armadilha Shannon, também foram coletadas manualmente formas aquáticas de imaturos. Oitocentos e sessenta e um dípteros foram capturados, incluindo Haemagogus leucocelaenus (Culicidae), Aedes albopictus (Culicidae), três espécies de Anopheles spp. (Culicidae), duas espécies de Plebotominae e três espécies de Simuliidae. A fauna de dípteros na área é diversificada e foram identificadas espécies com importância médica antes e após o enchimento do reservatório.

Palavras-chave: represas, Diptera, impacto ambiental, vetores.
The construction of hydroelectric plants causes relevant impact in the environment, mostly due to the modification of river hydrology, resulting in lakes covering extensive land areas. These modifications may alter communities composition and population dynamics of several organisms, including Diptera related to transmission of human diseases, like Culicidae (PAULA \& GOMES, 2007), Psychodidae (Phlebotominae) (REZENDE et al., 2009) and Simuliidae (ROSENBERG et al., 1997). In the last decade, many dams were erased along the Uruguai river, however very few data about the Diptera fauna with medical importance as vectorborne disease in this region are available. Therefore, the objective of this work was to survey Culicidae, Psychodidae (Phlebotominae) and Simullidae fauna as potential vectors of human infectious disease in the region of Foz do Chapecó Hydroelectric Station before and after the dam reservoir filling. This enterprise is located on Uruguai River in the borderland of Santa Catarina (municipality of Águas de Chapecó) and Rio Grande do Sul (municipality of Alpestre) Brazilian southern states with reservoir area of $79.2 \mathrm{Km}^{2}$ (2705'46.04”'S, 5301'05.66”'W).

Four collections were developed in eight Atlantic forest (Mixed ombrophilous) fragments (upper to $2.0 \mathrm{~km}^{2}$ ) allocate on the edge of the reservoir located in rural areas impacted by the dam reservoir. The collections were performed twice before reservoir filling in 2010 between March $20^{\text {th }}-23^{\text {th }}$

\footnotetext{
IÁrea de Ciências Biológicas e da Saúde, Universidade do Oeste de Santa Catarina (UNOESC), 89600-000, Joaçaba, SC, Brasil. E-mail: gecoazul@hotmail.com.*Autor para correspondência.

IIDepartamento de Microbiologia, Imunologia e Parasitologia, Centro de Ciências Biológicas, Universidade Federal de Santa Catarina (UFSC), Florianópolis, SC, Brasil.
} 
and July $2^{\text {nd }}-4^{\text {th }}$ and two times in 2011 after reservoir filling were completed (January $15^{\text {th }}-17^{\text {th }}$ and July $\left.15^{\text {th }}-17^{\text {th }}\right)$. Adult insects of Culicidae, Psychodidae (Phlebotominae) were collected during two distinct periods of the day, with the same effort, using suction tubes and lethal tubes (from 9 a.m. to 4 p.m) and using Shannon trap (from 6 p.m. to 8 p.m). Furthermore, immature live forms of Simuliidae were collected in small creeks using tweezers and pipettes in the same period of the day (MARCONDES, 2011). Diptera were identified by keys according to MARCONDES (2011), checking original and complementary descriptions of species.

Four-hundred eighty-one specimens of Culicidae belonging to 12 genera were collected, 222 (46.1\%) before and 259 (53.9\%) after reservoir filling. Ochlerotatus scapularis (11.9\%), O. serratus s.l. (6.5\%) and Anopheles galvaoi (4.6\%) were the most abundant species in the area (Table 1). The presence of Haemagogus leucocelaenus and Aedes albopictus in the area is epidemiologically very relevant. H. leucocelaenus is involved in sylvatic cycle of yellow fever in Brazilian state of Rio Grande do Sul (VASCONCELOS et al., 2003) and A. albopictus has been reported as a vector of several arboviruses (GRATZ, 2004). Since the impacted area by Foz do Chapecó Hydroelectric Station is situated in a transition area of yellow fever (YF) (VASCONCELOS et al., 2004), A. albopictus may be involved in the transition from sylvatic cycle of YF transmission to urban one (VASCONCELOS, 2002).

Although no human malaria has been reported in the area of this study, the presence of secondary vectors as $\boldsymbol{A}$. evansae, $\boldsymbol{A}$. galvaoi and $\boldsymbol{A}$. strode (CONSOLI \& LOURENÇO-DE-OLIVEIRA, 1994) should be emphasized. These Anopheles

Table 1 - Diptera collected before and after reservoir filling of Foz do Chapecó Hydroelectric Station, Santa Catarina and Rio Grande do Sul, Brazil.

\begin{tabular}{|c|c|c|c|}
\hline Diptera & Before N (\%) & After N (\%) & Total N (\%) \\
\hline \multicolumn{4}{|l|}{ Culicidae } \\
\hline Aedes albopictus & $3(0.4)$ & $1(0.1)$ & $4(0.5)$ \\
\hline Anopheles argyritarsis & $3(0.4)$ & $1(0.1)$ & $4(0.5)$ \\
\hline A. evansae & $0(0.0)$ & $4(0.5)$ & $4(0.5)$ \\
\hline A. galvaoi & $20(2.3)$ & $20(2.3)$ & $40(4.6)$ \\
\hline A. strodei & $10(1.2)$ & $12(1.4)$ & $22(2.6)$ \\
\hline Coquillettidia shannoni & $4(0.5)$ & $0(0.0)$ & $4(0.5)$ \\
\hline Culex (Culex) spp. & $15(1.8)$ & $1(0.1)$ & $16(1.9)$ \\
\hline C. (Melanoconion) spp. & $69(8.0)$ & $5(0.6)$ & $74(8.6)$ \\
\hline Haemagogus leucocelaenus & $0(0.0)$ & $8(0.9)$ & $8(0.9)$ \\
\hline Limatus durhamii & $12(1.4)$ & $26(3.0)$ & $38(4.4)$ \\
\hline Mansonia humeralis & $3(0.4)$ & $0(0.0)$ & $3(0.4)$ \\
\hline M. wilsoni & $0(0.0)$ & $4(0.5)$ & $4(0.5)$ \\
\hline Ochlerotatus crinifer & $5(0.6)$ & $11(1.3)$ & $16(1.9)$ \\
\hline O. fluviatilis & $2(0.2)$ & $2(0.2)$ & $4(0.5)$ \\
\hline O. scapularis & $55(6.4)$ & $47(5.5)$ & 102 (11.9) \\
\hline O. serratus s.l. & $2(0.2)$ & $54(6.3)$ & $56(6.5)$ \\
\hline Psorophora ferox & $3(0.4)$ & $6(0.6)$ & $9(1.0)$ \\
\hline Sabethes purpureus & $1(0.1)$ & $1(0.1)$ & $2(0.2)$ \\
\hline Trichoprosopon pallidiventer & $1(0.1)$ & $2(0.2)$ & $3(0.4)$ \\
\hline Uranotaenia apicalis & $1(0.1)$ & $0(0.0)$ & $1(0.1)$ \\
\hline Wyeomyia (Wyeomyia) spp. & $13(1.5)$ & $54(6.3)$ & $67(7.8)$ \\
\hline \multicolumn{4}{|l|}{ Psychodidae (Phlebotominae) } \\
\hline Nyssomyia neivai & $1(0.1)$ & $5(0.6)$ & $6(0.7)$ \\
\hline Pintomyia pessoai & $10(1.2)$ & $21(2.4)$ & $31(3.6)$ \\
\hline \multicolumn{4}{|l|}{ Simullidae } \\
\hline Simulium mariavulcanoae & $31(3.6)$ & $0(0.0)$ & 31 (3.6) \\
\hline S. nogueirai & $0(0.0)$ & $21(2.4)$ & $21(2.4)$ \\
\hline S. pertinax & $0(0.0)$ & $288(33.5)$ & $288(33.5)$ \\
\hline S. subnigrum & $0(0.0)$ & $3(0.4)$ & $3(0.4)$ \\
\hline Total & $264(30.7)$ & 597 (69.3) & $861(100.0)$ \\
\hline
\end{tabular}

Ciência Rural, v.44, n.7, jul, 2014. 
species, previously reported from Santa Catarina and Rio Grande do Sul, were considered responsible for autochthonous cases of malaria in some municipalities in Goiás state (MANOEL et al., 2010). Although Uranotaenia apicalis have been reported in the Brazilian state of São Paulo (DIBO et al., 2011), this is the first report of this specie in the South region of Brazil, regardless this specie is unrelated with vectorborne diseases.

Thirty-seven specimens of Phlebotominae (Nyssomyia neivai - $0.7 \%$ - and Pintomyia pessoai $3.6 \%)$ were collected in the crepuscule or night period (Table 1). One specimen of $\boldsymbol{N}$. neivai and ten of $\boldsymbol{P}$. pessoai were collected before reservoir filling, however the highest amount of these Phlebotominae specimens were collected after reservoir filling, representing five of $\boldsymbol{N}$. neivai and 21 of $\boldsymbol{P}$. pessoai. Both species have been reported as Leishmania braziliensis vectors and are found in both forest and human-modified environments (ANDRADE FILHO et al., 2007).

Three-hundred and forty-three immature specimens of Simullidae were collected from riverbeds in small creeks, 31 specimens (3.6\%) of Simulium mariavulcanoae, 21 (2.4\%) of $\boldsymbol{S}$. nogueirai, 288 (33.5\%) of $\boldsymbol{S}$. pertinax and three $(0.4 \%)$ of $\boldsymbol{S}$. subnigrum were collected (Table 1$)$. These species had already been reported in both Brazilian southern states. Interesting that only $\boldsymbol{S}$. mariavulcanoae was collected before the reservoir filling and the other three species of Simulium were found only after reservoir filling. Although these species have not been incriminated in transmission of Onchocerca volvulus, the high density of the population and their severe biting cause negative impact on human population (allergy) and on cattle (loss of weight and/or reduction of milk production) (MARCONDES, 2011).

Due to the small amount of sampling before and after reservoir filling, it was not possible to infer the modifications on Diptera fauna in the impacted area. However, this study shows an interesting Diptera fauna before and after reservoir filling, especially the potential vectors of human diseases, like A. albopictus, H. leucocelaenus, N. neivai and $\boldsymbol{P}$. pessoai. It indicates the need of continuous surveillance of Diptera populations in order to avoid the emergence of important tropical diseases in the area impacted by the reservoir of this hydroelectric.

\section{REFERENCES}

ANDRADE FILHO, J.D. et al. Nyssomyia intermedia (Lutz \& Neiva, 1912) and Nyssomyia neivai (Pinto, 1926) (Diptera: Psychodidae: Phlebotominae) geographical distribution and epidemiological importance. Memórias do Instituto Oswaldo
Cruz, v.102, p.481-487, 2007. Available from: <http://www. scielo.br/pdf/mioc/v102n4/5725.pdf/>. Accessed: May, 8, 2013. doi: doi.org/10.1590/S0074-02762007005000035.

CONSOLI, R.A.G.B.; LOURENÇO-DE-OLIVEIRA, R. Principais mosquitos de importância sanitária no Brasil. São Paulo: Fiocruz, 1994. 228p.

DIBO, M.R. et al. Presença de culicídeos em município de porte médio do Estado de São Paulo e risco de ocorrência de febre do Nilo Ocidental e outras arboviroses. Revista da Sociedade Brasileira de Medicina Tropical, v.44, p.496-503, 2011. Available from: <http://www.scielo.br/pdf/rsbmt/v44n4/19.pdf/>. Accessed: Jan, 30, 2013. doi: 10.1590/S0037-86822011000400019.

GRATZ, N.G. Critical review of the vector status of Aedes albopictus. Medical and Veterinary Entomology, v.18, p.215227, 2004. Available from: <http://onlinelibrary.wiley.com/ doi/10.1111/j.0269-283X.2004.00513.x/pdf/>. Accessed: Jan, 28, 2013. doi: 10.1111/j.0269-283X.2004.00513.x.

MANOEL, E.R. et al . Espécies de Anopheles (Diptera, Culicidae) em municípios com risco e autoctonia de malária no Estado de Goiás. Revista de Patologia Tropical, v.39, p.137-144, 2010. Available from: <http://www.revistas.ufg.br/index.php/iptsp/article/ view/10732/7131/>. Accessed: Dec, 13, 2012.

MARCONDES, C.B. Entomologia médica e veterinária. São Paulo: Atheneu, 2011. 526p.

PAULA, M.B.; GOMES, A.C. Culicidae (Diptera) em área de influência de construção de represa no Estado de São Paulo. Revista de Saúde Pública, v.41, p.284-289, 2007. Available from: <http://www.scielo.br/pdf/rsp/v41n2/5508.pdf/>. Accessed: Jan, 15, 2013. doi: 10.1590/S0034-89102006005000018.

REZENDE, H.R. et al. Efeitos da implantação da Usina Hidrelétrica de Rosal, Rio Itabapoana, Estados do Espírito Santo e Rio de Janeiro, sobre anofelinos, planorbídeos e flebotomíneos. Revista da Sociedade Brasileira de Medicina Tropical, v.42, p.160-164, 2009. Available from: <http://www.scielo.br/pdf/ rsbmt/v42n2/v42n2a13.pdf/>. Accessed: Jan, 11, 2013. doi: doi. org/10.1590/S0037-86822009000200013.

ROSENBERG, D.M. et al. Large-scale impacts of hydroeletric development. Environmental Reviews, v.5, p.27-54, 1997. Available from: <http://www.nrcresearchpress.com/doi/abs/10.1139/a97-001\#. UdJDFvm1FqV/>. Accessed: Jan, 12, 2013. doi: 10.1139/a97-001.

VASCONCELOS, P.F.C. Febre amarela: reflexões sobre a doença, as perspectivas para o século XXI e o risco da reurbanização. Revista Brasileira de Epidemiologia, v.5, p.244-258, 2002. Available from: <http://www.scielosp.org/pdf/rbepid/v5n3/04. pdf/>. Accessed: Jan. 16, 2013. doi: doi.org/10.1590/S1415790X2002000300004.

VASCONCELOS, P.F.C. et al. Isolations of yellow Fever virus from Haemagogus leucocelaenus in Rio Grande do Sul State, Brazil. Transactions of the Royal Society of Tropical Medicine and Hygiene, v.97, p.60-62, 2003. Available from: <http://iah.iec.pa.gov. br/iah/fulltext/pc/artigos/2003/TransRoySocTropMedHyg\%20 v97p60-62\%202003.pdf/>. Accessed: Jan, 17, 2013. doi: 10.1016/ S0035-9203(03)90023-X.

VASCONCELOS, P.F.C.et al. Genetic divergence and dispersal of yellow fever virus, Brazil. Emerging Infectious Diseases Journal, v.10, n.9, p.1578-1584, 2004. Available from: <http:// www.ncbi.nlm.nih.gov/pmc/articles/PMC3320275//>. Accessed: Jan. 17, 2013. doi: 10.3201\%2Feid1009.040197.

Ciência Rural, v.44, n.7, jul, 2014. 